Tim Vahle-Hinz, Katharina Kirschner, Maja Thomson*

\title{
Employment-related Demands and Resources - New Ways of Researching Stress in Flexible Work Arrangements**
}

Research into the relation between flexible work and health and well-being has been inconclusive so far. In this paper, empirical evidence is provided for the employment relationship as a new source of stress in flexible work. Employment-related demands and resources explain additional variance in levels of health and well-being beyond classic task-related aspects of stress. Furthermore, we show that control as a conventional task-related resource buffers the health impact of employment-related demands, highlighting the importance of considering both taskrelated and employment-related aspects of stress in flexible work arrangements.

Key words: stress, health, well-being, employment, flexibility

(JEL: I10, J81, O15)

* Dipl.-Psych. Tim Vahle-Hinz, University of Hamburg, Department of Work and Organizational Psychology, Von-Melle-Park 11, 20146 Hamburg, Germany.

E-mail: tim.vahle-hinz@uni-hamburg.de.

BSc. Katharina Kirschner, University of Hamburg, Department of Work and Organizational Psychology, Von-Melle-Park 11, 20146 Hamburg, Germany.

Dipl.-Psych. Maja Thomson, University of Hamburg, Department of Work and Organizational Psychology, Von-Melle-Park 11, 20146 Hamburg, Germany.

** Article received: December 31, 2011

Revised version accepted after double blind review: March 23, 2012.

management revue, 24(3), 199-221

ISSN (print) 0935-9915, ISSN (internet) 1861-9908
DOI 10.1688/1861-9908_mrev_2013_03_Vahle-Hinz

(C) Rainer Hampp Verlag, www.Hampp-Verlag.de 


\section{Introduction}

Over the last decades, employment has changed due to the demand for flexible work in a rapidly changing environment. A structural change to make employees' work attendance more flexible is the use of atypical work arrangements. For a long time, the standard employment contract specified permanent full-time employment. This form of employment remains the norm, but so-called atypical forms of employment (e.g. temporary work, fixed-term employment or part-time work) are becoming more important (OECD, 2002, 2010). Compared with permanent full-time employment, some studies reported a negative connection between atypical work arrangements and health (Benavides, Benach, Diez-Roux, \& Roman, 2000; Kattenbach, Demerouti, \& Nachreiner, 2010; Kivikäki et al., 2003), while others reported a positive relation (Butler, Grzywacz, Ettner, \& Liu, 2009; Costa, Sartori, \& Akerstedt, 2006; Guest, Isaksson, \& de Witte, 2010; Isaksson \& Bellagh, 2002). Some even report no relationship at all (Bernhard-Oettel, de Cuyper, Berntson, \& Isaksson, 2008; Bernhard-Oettel, Sverke, \& de Witte, 2005; Lundberg \& Lindfors, 2002).

What is clear is that the way we work has changed and that research comparing different forms of employment has thus far produced inconclusive results (de Cuyper et al., 2008). A different approach to studying health and well-being in flexible work is to assess new sources of stress in this kind of work rather than comparing different employment relationships. Specific stress stemming from the employment itself is not covered by classic stress-concepts like the Job Demand-Control model (JDC) (Karasek, 1979), which mainly covers task-related stress. New demands, such as the necessity to search for the next job or to balance multiple employers, and new resources, such as employment control, need to be considered. We propose that stress in flexible work needs to be assessed with regard to both task-related stress as well as employment-related stress.

The importance of the employment relationship for levels of health and wellbeing stems from its potential to influence effort as well as control and support at work in several ways. The employment relationship determines how much effort is needed to (1) search for employment, (2) stay in employment and (3) balance the demands of multiple employers and multiple worksites. It further determines how much control an employee has over (4) access to work itself and (5) the terms and conditions of work. Furthermore, the employment relationship influences (6) the amount of support at work, (7) the ability to satisfy domestic needs, and (8) the relationship between workers and their community through irregular work demands or work schedules (Lewchuck, de Wolff, King, \& Polanyi, 2005, p. 2).

This paper has three objectives: 1. Building on previous research, we extended the concept of employment-related stress. Specifically, we developed new scales measuring employment relationship demands and resources and empirically tested their relationship to health and well-being outcomes. 2. We tested for incremental validity of employment-related demands and resources beyond task-related aspects of stress. 3. We provide evidence that the interaction between task-related and employment-related aspects of stress influences health and well-being in atypical employment. Our study significantly advances the research on health and well-being in atypical employment as we provide empirical evidence for the importance of the employment re- 
lationship as an additional source of stress, and present information about a reliable and valid measuring instrument to assess this new source of stress.

\subsection{Beyond task-related stress}

The JDC (Karasek, 1979) distinguishes between demands (e.g. Does your work require you to work very fast?) and control or decision latitude (e.g. To what extent can you influence the content of your work?). High strain is to be expected if demands are high and control is low. An active job is one in which both demands and control are high. Several studies have shown that workers who are exposed to greater job strain experience negative health effects (de Lange, Taris, Kompier, Houtman, \& Bongers, 2003; Häusser, Mojzisch, Niesel, \& Schulz-Hardt, 2010). The ISO-strain concept (Johnson \& Hall, 1988) expanded on the JDC, adding the dimension of social support. According to this concept, whether workers experiences high or low strain also depends on the amount of social support they receive.

Lewchuk and colleagues used these theoretical frameworks of work stress to develop their concept of employment strain (Clarke, Lewchuk, de Wolff, \& King, 2007; Lewchuck, de Wolff, King, \& Polanyi, 2003, 2005; Lewchuk, Clarke, \& de Wolff, 2008). Employment strain goes beyond job strain and focuses on specific characteristics of flexible employment as a source of stress. Lewchuk and colleagues central argument is that "Karasek's job strain captures only one dimension of the controldemand-support trilogy at work, that being the dimension associated with the work process and the production of goods and services" (Lewchuck et al., 2005, p. 2). The key point of their argument is that work-related health effects can be divided into a task-related component and an employment-related component. Both are expected to explain variance in well-being independently of each other. In their work, Lewchuck et al. (2005) developed three dimensions of the employment relationship. These three dimensions are employment relationship workload (demand), employment relationship uncertainty (control) and employment relationship support. They showed that temporary agency, part-time, on-call, short-term contract and self-employed workers experience higher levels of employment strain than permanent full-time employees (Lewchuck et al., 2005; Lewchuk et al., 2008). With regard to health and well-being, they also showed that the components of employment strain are related to selfreported frequency of frustration, tension, stress, pain at work, exhaustion, workrelated sleep problems and headaches. Furthermore, these relations remain after controlling for sex, age, race, health status and formal employment relationship (Lewchuck et al., 2005; Lewchuk et al., 2008). Through a median split, they established four types of workers with different characteristics of employment strain similar to Karasek's model. These groups are low uncertainty (low employment relationship workload and low uncertainty), high uncertainty (low employment relationship workload and high uncertainty), bigh effort (high employment relationship workload and low uncertainty) and high employment strain (high employment relationship workload and high uncertainty). People in the high employment strain group are mainly, but not exclusively, on non-permanent contracts (Lewchuck et al., 2005). Furthermore, this group differed significantly from the low employment strain group regarding health and well-being (Lewchuk et al., 2008). The authors also tested whether high or low social support 
(constructed via median split) changes the relationship between the four groups and their respective levels of health and well-being. This assumption was partially confirmed for the high effort and the high uncertainty group, but not for the high employment strain group (Lewchuk et al., 2008).

\subsection{Employment strain or employment-related demands and resources?}

The concept of employment strain advances the possibilities to study health and wellbeing in flexible work arrangements. It offers a new take on operationalizing stress in a changing work environment. However, some criticism of this model of employment strain (Lewchuck et al., 2005) is worth addressing in order to further advance the research field. Firstly, the model builds on Karasek's JDC model, which has been criticized for its simplicity as it does not reflect all relevant aspects of the work-stress process (Bakker \& Demerouti, 2007). Specifically, the Job Demands-Resources model (JD-R) (Demerouti, Bakker, Nachreiner, \& Schaufeli, 2001) emphasizes the importance of resources for health and well-being at the workplace and highlights that control is not sufficient to describe work stress. Furthermore, it is argued that positive as well as negative aspects of work should be highlighted (Bakker \& Demerouti, 2007; Bakker, van Veldhoven, \& Xanthopoulou, 2010). The same holds true for Lewchuk et al.'s (2005) model of employment strain. Positive aspects of the employment relationship, such as learning opportunities due to multiple employers, are neglected. Secondly, research on the relationship between flexible working time and health and wellbeing suggests several constructs which are also important to consider. Janssen and Nachreiner (2005, 2004a, 2004b) showed that control, predictability and variability of working time are important aspects in the relationship between flexible working time and health and well-being. This is in accordance with McGrath and Beehr's (1990) work on stress. They emphasized the importance of time in the stress process. Specifically, they concluded that control over and predictability of the onset of a stressor are two major aspects in a time-related process of stress. Lewchuk et al. (2005) emphasized the importance of schedule uncertainty in precarious employment. This roughly reflects the dimension of predictability in McGrath and Beehr's (1990) as well as Janssen and Nachreiner's (2004b) frameworks. Another aspect - control over working time - needs to be considered, too. Thirdly, in order to highlight the importance of the employment relationship as an additional source of stress, it is important to empirically prove that employment-related aspects of stress explain variance in health and well-being outcomes beyond task-related aspects of stress. To our knowledge, this has not been done yet. We therefore addressed the following hypothesis:

Hypothesis 1: Employment-related stress goes beyond task-related stress: In addition to time pressure as a conventional task-related demand, employment-related demands explain variance in well-being (1a). In addition to control as a conventional task-related resource and social support, employment-related resources explain variance in well-being (1b).

We chose time pressure and control as task-related aspects of stress because they are most prominent in Karasek's JDC model. 
Concerning flexible characteristics of working time, it may remain unclear whether they are a demand or a resource. This is because a high level of schedule uncertainty is predicted to have a negative impact on well-being, whereas a low level is predicted to have a positive impact on well-being. We therefore view flexible characteristics of working time as independent of the theoretical notion of demands and resources and hypothesize accordingly:

Hypothesis 1c: In addition to time pressure, control and social support, characteristics of flexible working time explain variance in well-being.

Fourthly, task-related stress and employment-related stress may not be independent predictors of health and well-being, as Lewchuck et al. (2005) suggested. Specifically, it could be that in some jobs high employment-related demands (e.g. contract uncertainty) are buffered by task-related resources (e.g. learning opportunities). Therefore, the interaction between task-related demands and resources and employment-related demands and resources needs to be taken into account when explaining health and well-being in flexible work arrangements. We therefore addressed the following hypothesis:

Hypothesis 2: Employment-related demands and resources interact with task-related demands and resources. Specifically, control as a conventional taskrelated resource and social support both buffer the impact of employment-related demands on health and well-being (2a) and employment-related resources buffer the impact of time pressure as a conventional task-related demand on health and well-being (2b).

To address the aforementioned criticisms, two online surveys were conducted. In Study 1, a new instrument capable of measuring employment-related demands and resources was developed. In contrast to the approach taken by Lewchuk et al. (2005), more resources were measured and they were assessed in a positive way. Furthermore, items addressing characteristics of flexible working time were added to the instrument. Thus criticisms one and two were addressed.

In Study 2, the structure of the instrument was confirmed. We also tested hypothesis 1 and 2, thus addressing criticisms three and four.

\section{Study 1}

\subsection{Method}

\section{Procedure and sample}

In order to assess employment-related demands and resources, 42 items measuring 11 constructs were formulated as a starting point. We researched several measurement instruments that assess task-related demands and resources, trying to find constructs that could be transferred to an employment-related context. Most of the items were self-developed. Some, however, were formulated based on the instrument developed by Lewchuck et al. (2005), the stress-oriented task analysis (ISTA; Semmer, 1984; Semmer, Zapf, \& Dunckel, 1998), as well as questions used by Janssen and Nachreiner (2004b) to assess psychological aspects of flexible working time. University students who also work alongside their studies were asked to complete the survey. The study was publicized using a university intern website where students in need of 
participation credits can browse for studies to participate in. Additionally, students were contacted via social networks. We used this sample to conduct our study because we believe that working students face the employment situation we are interested in (i.e. they experience the pressure to balance the demands of studying and working). The survey website was visited by 218 people, of whom 179 began the questionnaire. Only 167 of them, however, completed the whole questionnaire and it was their data that we stored and analysed. Most participants were female $(70 \%)$ and the average age was $M=23.5$ years. Most worked 10-19 hours per week (54\%). The majority received financial support from their families (69\%). For 39\% of participants, their job was the main source of income. While $91 \%$ stated they work voluntarily, $40 \%$ stated they would quit their job if they could afford to do so.

\section{Analysis}

Item and reliability analysis as well as exploratory factor analysis (EFA) with a varimax rotation were conducted with the sample data using SPSS 18. The criteria for item selection were as follows: Cronbach's $\alpha>.60$ (Everitt \& Skrondal, 2010), an item-scale correlation $r_{i t} \geq .30$ (Ducki, 2000; Semmer, 1984), distinct assignment to one factor, fitting the content of the scale and interpretability of the exploratory factor solution (Bühner, 2011). As there is no set criterion for factor extractions in EFA, the results of the following factor extraction criteria were compared: theoretically proposed number of factors, eigenvalues $>1$, parallel analysis, minimum average partial test (MAP-Test) and scree test (Bühner, 2011).

\subsection{Results}

The selection process led to 37 items measuring 12 constructs. An EFA after the selection process showed good factor loadings ${ }^{1}(\lambda=.94-.52)$. For item-scale correlations, factor loadings and Cronbach's $\alpha$ for Sample 1, see Table 1. The variance explained by the 12 factors $(72.6 \%)$ is satisfactory (see Stevens, 2009).

\section{Description of the scales}

The instrument we developed consists of 12 scales (see Table 1$)^{2}$. These scales can be grouped into three theoretical dimensions, namely employment-related demands, employment-related resources and characteristics of flexible working time. Based on the JD-R model (Bakker \& Demerouti, 2007), employment-related demands require sustained physical and/or psychological effort. Employment-related resources aid in achieving employment-related goals, buffer employment-related demands, or stimulate personal growth. All items were answered on a five-point Likert scale. Most scales are similar to the concept of employment strain according to Lewchuk et al., who also provide an in-depth discussion of the scales relevance for health and well-being in flexible work arrangements (Lewchuck et al., 2005). However, the constructs of Lewchuk et al. (2005) were supplemented by our work. Particularly, the following aspects

1 One item, however, showed a factor loading of $\lambda<$. 40. It was nevertheless retained in the scale due to theoretical considerations.

2 The items are available (in German only) from the first author upon request. 
were added: the stressor (a) uncertainty about future employment, the resources (b) complexity due to multiple employers and (c) security when unemployed, as well as the characteristics of flexible working time (d) variability, (e) control, and (f) predictability. In the following description of all the scales that are part of the instrument, emphasis is put mostly on constructs which have not been discussed elsewhere.

Table 1: Cronbach's $\alpha$ and Item-Scale-Correlation for employment-related demands and resources

\begin{tabular}{lcccc}
\hline Scale & Number of items & $r_{\text {it }}$ & $a$ & $\lambda$ \\
\hline Effort keeping employment & 3 & $.51-.71$ & 0.76 & $.68-.81$ \\
Uncertainty about future employment & 3 & $.46-.54$ & 0.68 & $.58-.82$ \\
Uncertainty about work environment & 4 & $.49-.68$ & 0.79 & $.54-.82$ \\
Constant evaluation effort & 3 & $.54-.57$ & 0.73 & $.73-.84$ \\
Balancing multiple employers & 3 & $.43-.53$ & 0.67 & $.52-.76$ \\
Complexity due to multiple employers & 5 & $.53-.67$ & 0.82 & $.68-.84$ \\
Security when unemployed & 2 & 0.61 & 0.75 & .84 \\
Employment control & 2 & 0.54 & 0.70 & $.69-.80$ \\
Earnings control & 2 & 0.55 & 0.70 & $.79-.87$ \\
Working time control & 3 & $.36-.59$ & 0.66 & $.57-.79$ \\
Working time predictability & 4 & $.34-.86$ & 0.84 & $.37-.94$ \\
Working time variability & 3 & $.47-.65$ & 0.75 & $.56-.84$ \\
\hline
\end{tabular}

Note. $N=167$

Employment-related demands. This construct consists of five aspects. The scale for effort to keep employment operationalizes the pressure on employees in flexible work arrangements to find new employment within a short period of time. It further assesses the effort and the time needed to invest in order to search for employment. An example item is: "How often are you under pressure to find work as soon as possible?" (1 "rarely" to 5 "very often").

The scale for constant evaluation effort assesses the demand on employees in flexible work arrangements to constantly prove that they are doing good work and therefore should be kept in employment. An example item is: "Exceptionally good work is required in order to keep employment." (1 "disagree" to 5 "strongly agree").

The possibility of losing a job encompasses the threat of not being able to fulfill basic work-related needs (de Witte, 1999; Jahoda, 1982). Several studies have highlighted the impact of job insecurity on workers' health and well-being (D'Souza, Strazdins, Broom, Rodgers, \& Berry, 2006; Reisel, Probst, Chia, Maloles, \& König, 2010; Sverke, Hellgren, \& Näswall, 2002). In flexible work, employees often do not know if their contracts will be extended. They commonly experience periods of unemployment (Benach, Benavides, Platt, Diez-Roux, \& Muntaner, 2000; Polivka, 1996). It can be concluded that the prospect of future unemployment has a negative relation 
to health and well-being in flexible work arrangements. Therefore, a scale assessing uncertainty about future employment was included. An example item is: "I expect to become unemployed." (1 "disagree" to 5 "strongly agree").

As employees in flexible work arrangements often have more than one employer and work at different sites, the demands balancing multiple employers and uncertainty about work environment were included. An example item for uncertainty about work environment is: "Due to your employment relationship, how often are you unaware of safety regulations at your site of work?" (1 "rarely" to 5 "very often"). An example item for balancing multiple employers is: "How often do you have time-related problems because several of your work-related responsibilities coincide?" (1 "rarely" to 5 "very often").

Employment-relationship resources. This construct consists of four aspects. Two different categories of control are assessed: Employment control and earnings control. An example item for employment control is: "To what extent can you control that you have work?" (1 "very little" to 5 "very much"). An example item for earnings control is: "Can you estimate how much you will earn in the next month?" (1 "never" to 5 "always"). The scale for complexity due to multiple employers assesses a quite different aspect. It represents a potentially positive aspect of flexible work arrangements because multiple employers, despite being a source of demand, might offer learning opportunities. A changing work environment, the requirement to organize and combine different needs of various employers, and new and therefore possibly challenging tasks are aspects through which flexible employees might expand their skills and learn new things. Learning opportunities are thought to positively influence the personality and wellbeing of workers (Bakker et al., 2010; Rau, 2006). Action regulation theory (Hacker, 2002, 2003), the JD-R model (Demerouti et al., 2001), and the job characteristics model (Hackman \& Oldham, 1980) all emphasize the importance of challenging aspects of work and their significance for health and well-being. An example item is: "I learn new things because I have multiple employers." (1 "disagree" to 5 "strongly agree").

The scale for security when unemployed assesses the belief that new employment will be found once unemployed. An example item is: "If I am unemployed, my chances of finding a new job are high."(1 "disagree" to 5 "strongly agree"). This resource is very similar to the concept of employability (Hillage \& Pollard, 1998). Perceived employability is seen as a worker's perception of his or her ability to get a new or equal job (Berntson \& Marklund, 2007; Berntson, Sverke, \& Marklund, 2006). De Cuyper, van der Heijden and de Witte (2011) have stated that perceived employability indicates control over one's work life and therefore resembles resources discussed in the JD-R model (Demerouti et al., 2001). Indeed, several studies confirm the positive relationship between employability and well-being (Berntson \& Marklund, 2007; de Cuyper, Bernhard-Oettel, Berntson, de Witte, \& Alarco, 2008). Furthermore, this relationship was shown to be mediated by job insecurity (de Cuyper et al., 2008). Berntson, Näswall and Sverke (2010) suggest that highly employable workers are not likely to keep their insecure (and unhealthy) job, but rather move on. The scale for security when unemployed was included in the instrument because the belief that new employment can be found relatively easily is proposed to be beneficial to health when working under 
unstable market conditions. This is especially relevant for workers in flexible work arrangements (Benach, Amable, Muntaner, \& Benavides, 2002).

Janssen and Nachreiner (2004a, 2004b) as well as others (Costa et al., 2004; Costa, Sartori, \& Akerstedt, 2006) have demonstrated the importance of variability, predictability and control for the relationship between working time and health and wellbeing. In their studies, they showed that highly variable working time negatively affects levels of health and well-being. Yet they also indicated that this is only the case if working time is not predictable and the employee has no control over allocation of working time (Janssen \& Nachreiner, 2004b). Clearly, characteristics of flexible working time are important for health and well-being. Thus, three scales based on Janssen and Nachreiner's work (2004b) as well as on the measurement of schedule uncertainty by Lewchuk et al. (2005) were developed. Some example items are: "I know about my working time long enough to plan my week's tasks" (predictability); "It is possible for me to change my working time on short notice" (contro); "All in all my working time varies greatly" (variability). The items for predictability and variability range from 1 "disagree" to 5 "strongly agree", and the items for control range from 1 "always" to 5 "never".

Lewchuck et al. (2005) already included questions regarding predictability of working time in their framework. The other aspects, however, were not included.

\section{Study 2}

\subsection{Method}

\section{Procedure and sample}

Several on-call workers at publicity agencies were contacted in order to recruit participants. These workers are mainly booked for promotional activities (e.g. handing out flyers) and work on a self-employed basis. We chose on-call workers because they typically work in more than one job and, since they work on a self-employed basis, they are likely to face uncertainty regarding their next assignment. We first approached agencies by letter, inviting them to participate in our study. Once they accepted, all oncall workers registered in an agency's database received an e-mail with a request for participation and a link to the online survey. A total of 740 on-call workers used the link and started the online questionnaire. Of those, 512 completed all questions covering employment-related demands and resources as well as social demography. The sample consists mainly of female on-call workers (86\%), the mean age is $M=27$ years, $90 \%$ have a university-level education and 63\% live with a partner. Besides their work, $68 \%$ of participants are in education (mainly university). They have been working oncall for 1-3 years (34\%). Their mean working hours per week are $M=15$ hours. While $46 \%$ support themselves through their work alone, 54\% receive additional funding (e.g., family support or benefits). Nearly all participants stated that they work voluntarily on-call $(92 \%)$, and $62 \%$ stated that they do not with to be permanently employed. However, $48 \%$ stated that they would quit their job if they could afford to do so. 


\section{Measurements}

Employment-related demands and resources as well as characteristics of flexible working time were assessed using the measurement instrument described above. The scales showed satisfactory reliability in this sample (Cronbach's $\alpha$ ranging from .63 to .92).

As research concerning the impact of atypical employment on health and wellbeing emphasizes that it is important whether employees voluntarily work in their employment relationship (Ellingson, Gruys, \& Sackett, 1998; Guest, 2004; Krausz, 2000; Marler, Woodard, Barringer, \& Milkovich, 2002), items assessing the desire to change one's job if possible (1 "yes", 2 "no") and whether participants work voluntarily on-call (1 "yes", 2 "no") were included in the analysis as possible confounding factors.

Task-related demands and resources were assessed with the subscales time pressure (Cronbach's $\alpha=.83$ ) and control (Cronbach's $\alpha=.82$ ) taken from the ISTA (Semmer et al., 1998). Support from family and friends was assessed using the social support scale (Cronbach's $\alpha=$.91) by Zimet, Dahlem, Zimet and Farley (1988).

Additionally, several ways of measuring well-being were included:

Satisfaction with life was assessed with the short version of the Satisfaction With Life Scale (SWLS; Diener, Emmons, Larsen, \& Griffin, 1985). On the SWLS, participants rated their agreement with five statements on a seven-point Likert scale (1 "strongly disagree" to 7 "strongly agree"). The SWLS showed high reliability in this sample (Cronbach's $\alpha=.91$ ).

Psychosomatic complaints were assessed using a 20-item scale developed by Mohr and Müller (2005). Participants were asked to rate the frequency of health complaints on a five-point Likert scale ( 1 "never" to 5 "almost daily"). Reliability was high in this sample (Cronbach's $\alpha=.91)$.

Irritation measures emotional and cognitive work-related strain (Mohr, Rigotti, \& Müller, 2005). All items were answered on a seven-point Likert scale (1 "I strongly disagree" to 7 "I strongly agree"; Cronbach's $\alpha$ in this sample $=.90$ ).

Furthermore, we assessed burnout using the subscale for weariness of work from the Hamburg Burnout Inventory (HBI; Burisch, 2007). Items were answered on a seven-point Likert scale (1 "not applicable" to 7 "applicable"). The scale showed very high reliability in this sample (Cronbach's $\alpha=.94)$.

\section{Analysis}

To confirm the structure of the instrument used, a confirmatory factor analysis (CFA) using AMOS 18 was conducted. Using maximum-likelihood estimation we corrected for non-normality with Boline-Stine-Bootstrap correction (Kline, 2005).

To address hypothesis 1 we conducted a hierarchical regression analysis. To address hypothesis 2 we performed a series of moderated regression analyses and addressed all interactions separately. Table 2 shows the relations between all study variables. With regard to the moderated regression analyses, z-transformation was conducted prior to calculating the interaction term. Not all participants provided data on all dependent variables. We used listwise deletion to exclude missing data. 


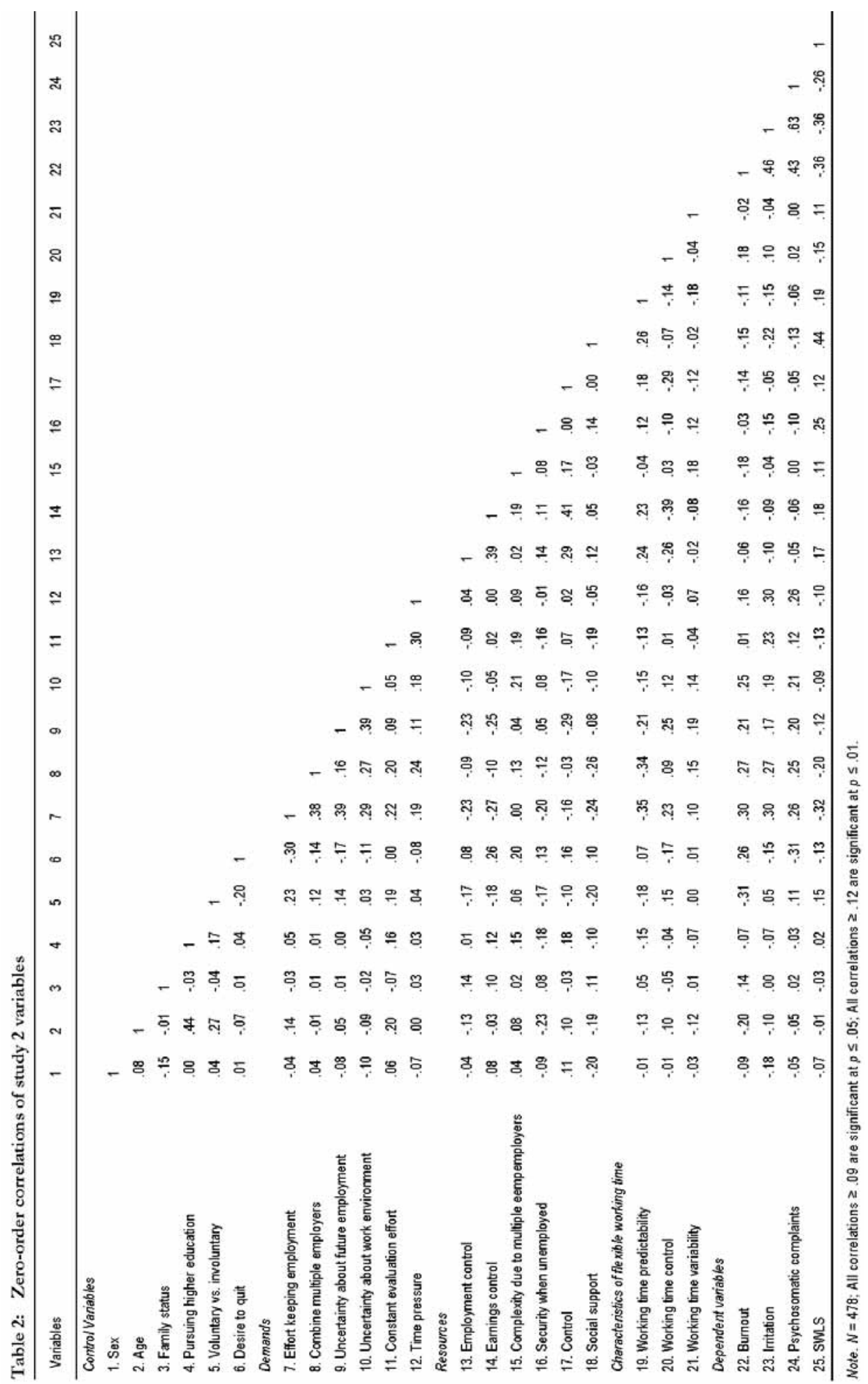




\subsection{Results}

\section{Confirming the instrument's structure}

Table 3 presents the results of a one-factor solution as well as the proposed 12-factor solution. The fit of the 12 -factor model is better than that of the one-factor solution $\left(\Delta \chi^{2}=5503.01 ; \Delta d f=6 ; p \leq .01\right)$. The assumption of multivariate normality is violated (Mardia's Test), but all items are within the boundaries for skew $(<2)$ and kurtosis $(<7)$ recommended by Curran, West and Finch (1996). We report fit indices recommended by $\mathrm{Hu}$ and Bentler (1999). The RMSEA and SRMR for the 12-factor solution are within the recommended boundaries (RMSEA < .06; SRMR < .08; Browne \& Cudeck, 1993; Hu \& Bentler, 1999). In combination with other fit indices, a more progressive cut-off for the CFI (>.90) is acceptable (Bentler \& Bonett, 1980; Hu \& Bentler, 1999; Kline, 2005). As $\chi^{2}$ depends on sample size, its significance should not automatically result in rejection of the model. Divided by the degrees of freedom, a standardized chi-square $\left(\chi^{2} / \mathrm{df}\right)$ between $2-3$ is proposed to be acceptable (Moosbrugger \& Schermelleh-Engel, 2007). In summary, the fit of the 12-factor is acceptable.

Table 3: Results of the confirmatory factor analysis (CFA)

\begin{tabular}{llccccccc}
\hline Model & $x^{2}$ & $\mathrm{df}$ & $\mathrm{p}$ & $\mathrm{X}^{2 / \mathrm{df}}$ & SRMR & RMSEA & $\begin{array}{l}90 \% \mathrm{Cl} \\
\text { RMSEA }\end{array}$ & $\mathrm{CFI}$ \\
\hline $\begin{array}{l}\text { One } \\
\text { Factor }\end{array}$ & 6911.48 & 665 & .000 & 10.39 & .129 & .136 & $.133-.138$ & .259 \\
\hline 12 Factor & 1408.47 & 599 & .000 & 2.35 & .064 & .051 & $.048-.055$ & .904 \\
\hline
\end{tabular}

Note. $N=512, \Delta X^{2}=5503.01 ; \Delta d f=6 ; p \leq .01$

\section{Relationship to health and well-being - direct and interactional effects}

Hypothesis 1: Employment-related stress goes beyond task-related stress

1a In addition to time pressure as a conventional task-related demand, employment-related demands explain variance in wellbeing.

Model 1 in Table 4 shows the results of the hierarchical multiple regression analysis with the predictors employment-related demands and time pressure as a conventional task-related demand. Employment-related demands add significantly to the model regarding all dependent variables $\left(\Delta \mathrm{R}^{2}=.04\right.$ to $\left..08, p \leq .01\right)$. Furthermore, the influence of time pressure remains significant only when predicting psychosomatic complaints $(\beta$ $=.16, p \leq 01)$ and irritation $(\beta=.19, p \leq .01)$. When it came to employment-related demands, the effort to keep employment $(\beta=-.18, p \leq .01)$ showed a significant effect on SWLS. The demands balancing multiple employers $(\beta=.13, p \leq .01)$ and effort to keep employment $(\beta=.12, p \leq .05)$ showed a significant effect on psychosomatic complaints. The effort to keep employment $(\beta=.13, p \leq .05)$, the demands balancing multiple employers ( $\beta$ $=.13, p \leq .01)$ and uncertainty about the work environment $(\beta=.12, p \leq .05)$ showed a significant effect on burnout. Lastly, the effort to keep employment $(\beta=.14, p \leq .01)$, the de- 
mands balancing multiple employers $(\beta=.12, p \leq .05)$ and constant evaluation effort $(\beta=.12, p$ $\leq .05)$ all showed a significant effect on irritation.

Only the predictor uncertainty about future employment did not show a significant effect on any of the dependent variables. These findings support hypothesis $1 \mathrm{a}$.

$1 \mathrm{~b}$ In addition to control as a conventional task-related resource and social support, employment-related resources explain variance in well-being.

Model 2 in Table 4 shows the results of the hierarchical multiple regression analysis with employment-related resources. These predictors significantly affect one of the four dependent variables, namely SWLS $\left(\Delta \mathrm{R}^{2}=.02, p \leq .01\right)$. Complexity due to multiple employers $(\beta=-.12, p \leq .01)$ proved to be a significant predictor of burnout while security when unemployed proved to be a significant predictor of irritation $(\beta=-.12, p \leq .01)$, psychosomatic complaints $(\beta=-.11, p \leq .05)$ and SWLS $(\beta=.13, p \leq .01)$.

Additionally, social support is a significant predictor of all dependent variables $(\beta=$ -.15 to $.36, p \leq .01)$, whereas control does not significantly predict any of the dependent variables $(\beta=-.04$ to $.06, p=\mathrm{ns})$.

Hypothesis $1 \mathrm{~b}$ is partially supported.

1c In addition to time pressure, control and social support, characteristics of flexible working time explain variance in well-being.

Model 3 in Table 4 shows the results of the hierarchical multiple regression analysis with characteristics of flexible working time, time pressure, control and social support as predictors. Characteristics of flexible working time explain a significant amount of variance in the items referring to burnout $\left(\Delta \mathrm{R}^{2}=.02, p \leq .05\right)$ and SWLS $\left(\Delta \mathrm{R}^{2}=.02, p\right.$ $\leq .01)$. Control over working time $(\beta=.12, p \leq .01)$ is a significant positive predictor of burnout, whereas variability of working time $(\beta=.13, p \leq .01)$ is a significant positive predictor of SWLS.

When it comes to task-related demands and resources, time pressure $(\beta=-.08$ to $.28, p \leq .05)$ appears to be a significant predictor of all dependent variables and control is a significant predictor of SWLS $(\beta=.09, p \leq .05)$. Furthermore, social support is a significant predictor of all dependent variables $(\beta=-.20$ to $.36, p \leq .01)$.

Hypothesis 1c is partially supported. 
Table 4: Hierarchical regression analysis predicting levels of health and well-being from demands (Model 1), resources (Model 2) and characteristics of flexible working time (Model 3)

\begin{tabular}{|c|c|c|c|c|c|c|c|c|}
\hline \multirow[b]{2}{*}{ Step Variable } & \multicolumn{2}{|c|}{ Burnout } & \multicolumn{2}{|c|}{ Irritation } & \multicolumn{2}{|c|}{$\begin{array}{l}\text { Psychosomatic } \\
\text { complaints }\end{array}$} & \multicolumn{2}{|c|}{ SWLS } \\
\hline & $\beta$ & $\Delta \mathrm{R}^{2}$ & $\beta$ & $\Delta \mathrm{R}^{2}$ & $\beta$ & $\Delta \mathrm{R}^{2}$ & $\beta$ & $\Delta \mathrm{R}^{2}$ \\
\hline Step 1 & & $.11^{* *}$ & & $.04^{* *}$ & & $.07^{\star *}$ & & $.17^{* \star}$ \\
\hline \multicolumn{9}{|l|}{ Control variables } \\
\hline \multicolumn{9}{|l|}{ Model 1: Demands } \\
\hline Step 2 & & $.02^{\star \star}$ & & $.08^{* *}$ & & $.06^{\star *}$ & & $.01^{*}$ \\
\hline Time pressure & .08 & & $.19^{* *}$ & & $.16^{\star *}$ & & -.04 & \\
\hline Step3 & & $.08^{* *}$ & & $.07^{\star *}$ & & $.06^{\star *}$ & & $.04^{* *}$ \\
\hline $\begin{array}{l}\text { Uncertainty about future em- } \\
\text { ployment }\end{array}$ & .05 & & .03 & & .07 & & .03 & \\
\hline Balancing multiple employers & $.13^{* \star}$ & & $.12^{\star}$ & & $.13^{* *}$ & & -.08 & \\
\hline Constant evaluation effort & -.07 & & $.12^{*}$ & & .04 & & .01 & \\
\hline $\begin{array}{l}\text { Uncertainty about work environ- } \\
\text { ment }\end{array}$ & $.12^{*}$ & & .05 & & .05 & & -.01 & \\
\hline Effort keeping employment & $.13^{*}$ & & $.14^{* \star}$ & & $.12^{*}$ & & $-.18^{* *}$ & \\
\hline $\mathrm{R}^{2}$ & & .20 & & .19 & & .18 & & .21 \\
\hline $\mathrm{R}^{2}$ adj. & & .18 & & .17 & & .16 & & .19 \\
\hline \multicolumn{9}{|l|}{ Model 2: Resources } \\
\hline Step 2 & & $.02^{\star *}$ & & $.04^{* *}$ & & $.03^{\star *}$ & & $.13^{* *}$ \\
\hline Control & -.04 & & .01 & & .01 & & .06 & \\
\hline Social support & $-.15^{* *}$ & & $-.21^{* *}$ & & $-.17^{* *}$ & & $.36^{* *}$ & \\
\hline Step3 & & .02 & & .02 & & .01 & & $.02^{* \star}$ \\
\hline Employment control & -.01 & & -.05 & & -.03 & & .03 & \\
\hline Earnings control & -.04 & & -.00 & & .01 & & .02 & \\
\hline $\begin{array}{l}\text { Complexity due to multiple em- } \\
\text { ployers }\end{array}$ & $-.12^{* *}$ & & -.01 & & .05 & & .07 & \\
\hline Security when unemployed & .03 & & $-.12^{* *}$ & & $-.11^{*}$ & & $.13^{* *}$ & \\
\hline $\mathrm{R}^{2}$ & & .15 & & .10 & & .11 & & .32 \\
\hline $\mathrm{R}^{2}$ adj. & & .13 & & .08 & & .08 & & .30 \\
\hline \multicolumn{9}{|c|}{ Model 3: Characteristics of flex. working time } \\
\hline Step 2 & & $.02^{* *}$ & & $.04^{* *}$ & & $.03^{* *}$ & & $.13^{* *}$ \\
\hline Control & -.05 & & -.00 & & .00 & & $.09^{*}$ & \\
\hline Social support & $-.13^{* *}$ & & $-.20^{* *}$ & & $-.17^{* *}$ & & $.36^{* *}$ & \\
\hline Step3 & & $.02^{* *}$ & & $.08^{\star *}$ & & $.05^{\star *}$ & & .01 \\
\hline Time pressure & $.14^{* \star}$ & & $.28^{* \star}$ & & $.23^{\star \star}$ & & $-.08^{*}$ & \\
\hline Step 4 & & $.02^{*}$ & & .01 & & .00 & & $.02^{* *}$ \\
\hline Working time predictability & -.02 & & -.05 & & -.00 & & .04 & \\
\hline Working time control & $.12^{\star \star}$ & & .06 & & -.01 & & -.03 & \\
\hline Working time variability & -.05 & & -.09 & & -.04 & & $.13^{* *}$ & \\
\hline$R^{2}$ & & .17 & & .17 & & .15 & & .32 \\
\hline $\mathrm{R}^{2}$ adj. & & .15 & & .15 & & .12 & & .30 \\
\hline
\end{tabular}

Note. $N=478,{ }^{*} p \leq .05 ;{ }^{*} p \leq .01,1-\beta=.64$ to .99 , beta-weights originate from the final model. Control variables: Sex, age, family status, pursuing an educational degree, voluntary vs. involuntary, desire to quit. 
Hypothesis 2: Employment-related demands and resources interact with task-related demands and resources and social support.

2a Control as a conventional task-related resource and social support both buffer the impact of employment-related demands on health and well-being.

Several significant interactions were found between employment relationship demands, control and social support. With regard to SWLS, effort to keep employment $(\beta=.11, p$ $\left.\leq .05, \Delta \mathrm{R}^{2}=.01\right)$ and constant evaluation effort $\left(\beta=.18, p \leq .01, \Delta \mathrm{R}^{2}=.03\right)$ showed a significant interaction with control. As shown in Figure 1, SWLS remains constant for the high control group, whereas it decreases for the low control group when constant evaluation effort is high. The interaction between effort to keep employment and control shows that SWLS decreases more in the low control group if the stressor value is high (not shown in Figure 1).

Furthermore, effort to keep employment $\left(\beta=.12, p \leq .01, \Delta \mathrm{R}^{2}=.01\right)$ shows a significant interaction with social support. As can be seen in Figure 2, SWLS decreases more in the low social support group when effort to keep employment is high.

Figure 1: Interaction between constant evaluation effort (CEE) and control on SWLS

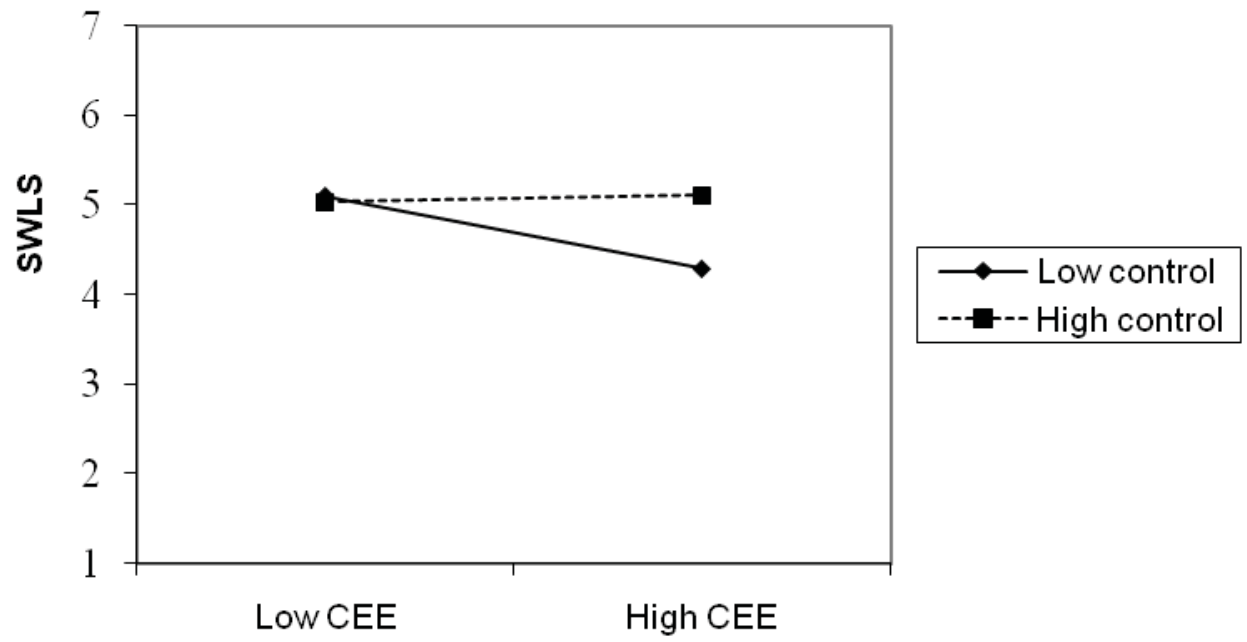


Figure 2: Interaction between effort keeping employment (EKE) and social support on SWLS

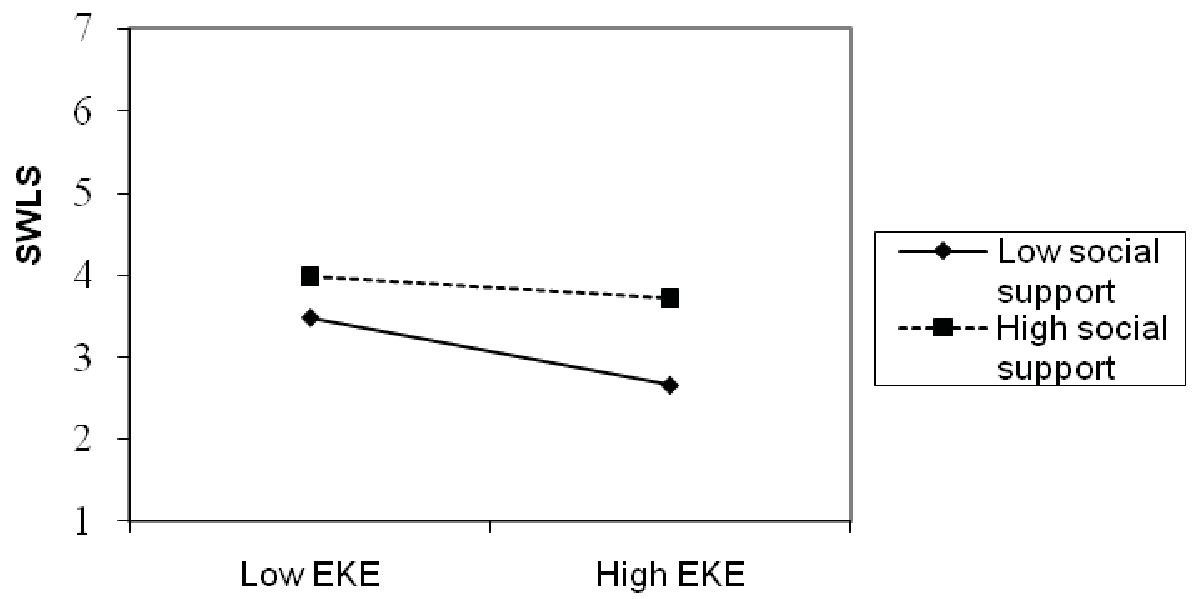

Concerning psychosomatic complaints, constant evaluation effort $\left(\beta=-.17, p \leq .01, \Delta \mathrm{R}^{2}=\right.$ .03) showed a significant interaction with control. Figure 3 shows a slight decrease for the high control group and an increase for the low control group when constant evaluation effort is high.

Figure 3: Interaction between constant evaluation effort (CEE) and control on psychosomatic complaints

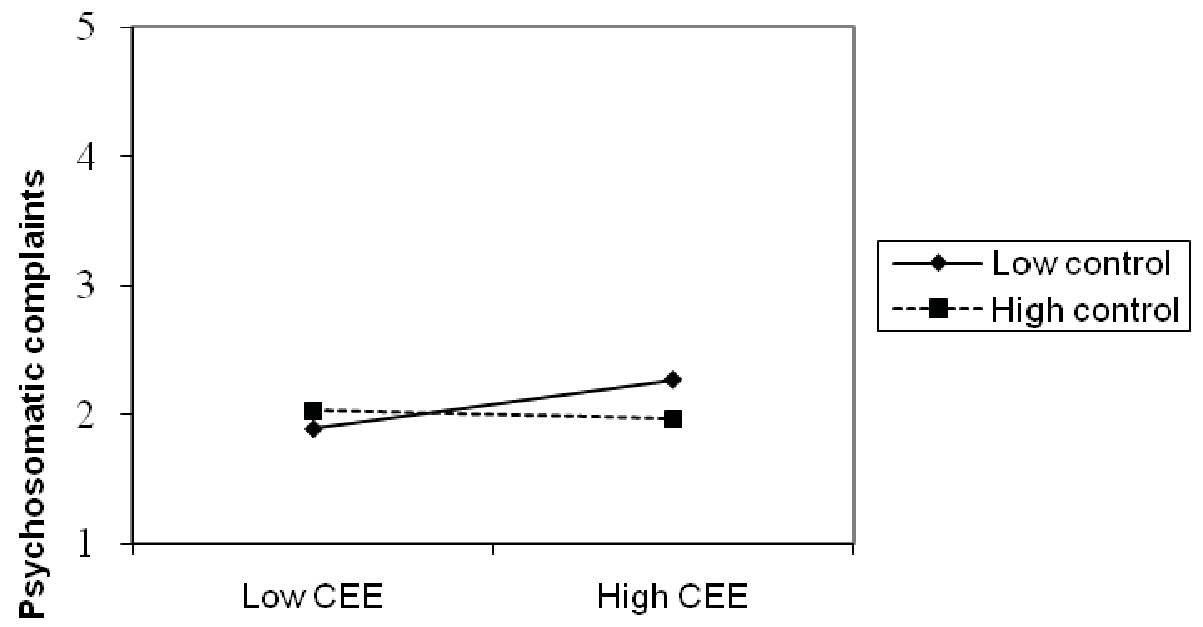

Irritation increases more for the low control group compared to the high control group when effort to keep employment $\left(\beta=-.12, p \leq .01, \Delta \mathrm{R}^{2}=.01\right)$ or constant evaluation effort are high $\left(\beta=-.11, p \leq .05, \Delta \mathrm{R}^{2}=.01\right)$. Figure 4 shows this interaction for constant evaluation effort. The interaction with effort to keep employment is similar (not shown in Figure 4). 
Figure 4: Interaction between constant evaluation effort (CEE) and control on irritation

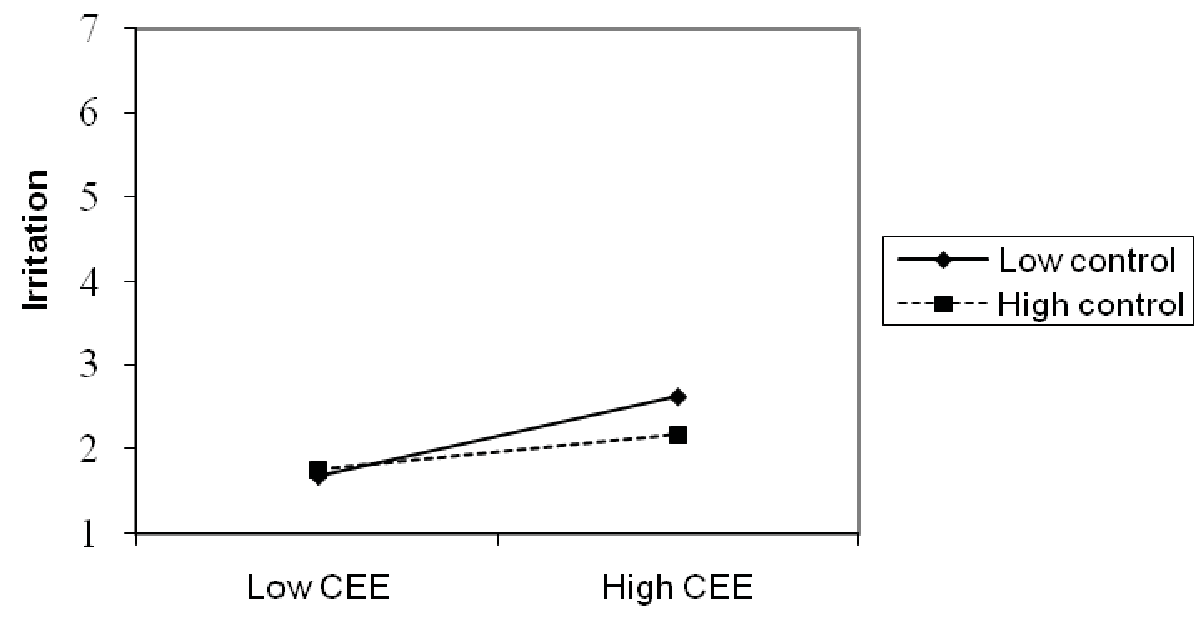

Concerning burnout, uncertainty about the work environment shows a significant interaction with control $\left(\beta=.16, p \leq .01, \Delta R^{2}=.03\right)$. For the high control group, burnout is low when uncertainty about the work environment is low, but it increases greatly when uncertainty about the work environment is high. Figure 5 illustrates this.

Figure 5: Interaction between uncertainty about work environment (UWE) and control on burnout

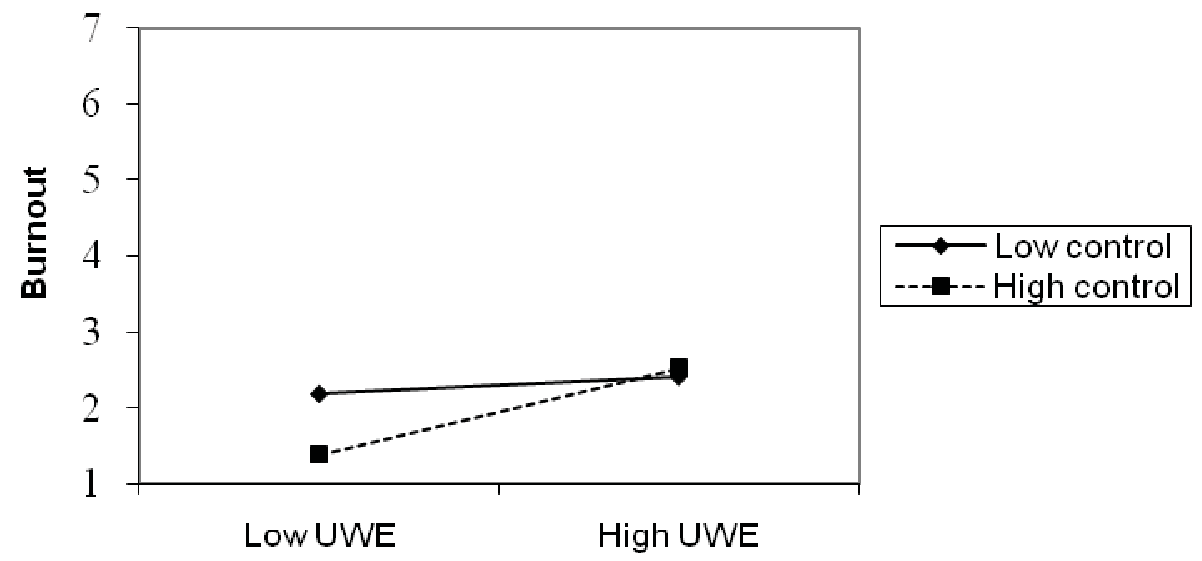

Mostly, control and social support show the proposed buffering effect. However, this is not true of burnout and uncertainty about future employment. Hypothesis 2a is partially supported. 
2b Employment-related resources buffer the impact of time pressure as a conventional task-related demand on health and wellbeing.

There are no significant interactions between time pressure and any of the employmentrelated resources. Hypothesis $2 \mathrm{~b}$ is rejected.

\section{Discussion}

The results presented in this article are based on a reliable and valid instrument which measures important aspects of employment-related stress. The results support the notion that employment-related demands and resources go beyond task-related demands and resources. Hierarchical multiple regression analysis showed that by adding employment-related demands to the equation, $4-8 \%$ additional variance in all dependent variables can be explained. Concerning employment-related resources, additional variance is only explained in SWLS. This is not surprising, given that the dependent variables are mainly negative aspects of well-being, whereas resources are thought to correlate more with positive aspects of well-being (Bakker et al., 2010). It is noteworthy, however, that complexity due to multiple employers and security when unemployed appear to be significant predictors in the model. These resources have not been analysed elsewhere. This highlights how important it is to search for more resources in flexible work and to not underestimate the influence of these aspects on health and well-being. In order to test the relevance of resources, future studies should include more positive aspects of well-being.

Characteristics of flexible working time explain unique variance beyond traditional task-related demands and resources in a sample of on-call workers. This further demonstrates the importance of these aspects for health and well-being in flexible work. However, the positive influence of working time variability on SWLS is, in light of existing literature, puzzling. High variability is related to poorer health outcomes in a study by Janssen and Nachreiner (2004b). The characteristics of our sample may explain the results of our study. The sample consists mainly of young people who do not work full-time but rather to finance their education. For this group, variable working times might help to balance educational and financial demands. It should be investigated, however, whether the positive influence of working time variability can be replicated in a sample of older full-time workers.

Time pressure remains a significant predictor of irritation and psychosomatic complaints when employment-related demands are added to the model. It loses significance, however, when its effects on SWLS and burnout are tested. This result indicates that time pressure may not be as important as employment-related demands for the current sample. As research confirmed the importance of conventional task-related stress, we believe its impact might be stronger in other samples. We therefore highly recommend studying both aspects of stress in flexible work.

Social support proves to be a strong significant predictor of all our dependent variables. As general social support was assessed, this result endorses Lewchuk et al.'s (2005) notion that support outside the workplace is important in flexible work arrangements. Future studies should differentiate between general and work-related support. Specifi- 
cally, it should be empirically tested which one of the two is more important for workers in flexible work arrangements.

Control and social support were found to have a buffering effect on employmentrelated demands in Study 2. If control and, to a lesser extent, social support are high, wellbeing remains stable or decreases more slowly when stressors are high. A possible explanation for the buffering effect of control on the effort to keep employment is that workers who have a high degree of control over the tasks they perform may enjoy these tasks more. This in turn outweighs the effort of finding work. Furthermore, the results suggest that workers who are under pressure to prove themselves at work benefit from control. One possible explanation may be that they feel they have a fair chance to avoid failure because shaping the task is in their hands.. The results also show an adverse effect of control, however. If workers do not know much about their work environment, it appears to be disadvantageous if they have a great deal of control over their task. In this case, control may further increase insecurity. This is because lacking knowledge about the work environment also means workers do not know where to get relevant information. They are therefore unable to use the level of freedom they have been given. This result and corresponding interpretation require replication in future studies.

It should be noted that employment-related demands and resources are not independent of task-related demands and resources. Both aspects should be considered in their interaction. This is important for health-related workplace interventions: In flexible work, task-related aspects of stress and employment-related aspects of stress as well as their interaction all determine whether a job is healthy or not.

Time pressure did not interact with any of the employment-related resources, which does not support our hypothesis. As suggested earlier, time pressure may not be as important for health and well-being in our sample, which consists mainly of people pursuing a degree and working part-time. In future studies, other aspects of task-related stress (e.g., work overload) should be included.

In our analysis, we included as confounding factors whether participants voluntarily chose on-call work and whether they would quit their job if financially possible. The results show that employment-related demands and resources as well as characteristics of flexible working time explain, at least partially, additional variance even when these confounding factors are included. The inclusion of these important confounding factors in analyses is uncommon and is an advantage of our study.

Uncertainty about future employment is the only demand which proved not to be a significant predictor of any of the dependent variables. Job insecurity may be more important for some flexible workers than for others (Benach et al., 2002). Job insecurity may not be as important in our sample as in others because the majority of participants in our study do not expect to work on-call for a long time.

\subsection{Limitations}

This study has some limitations that could be addressed in future studies. Firstly, both samples consist mainly of very young participants in higher education. Therefore, their jobs may not be as important to them as to other workers who do not pursue other career goals outside their current employment. The effect of conventional task-related 
demands and resources may thus be underestimated, although the factor pursuing an educational degree was controlled for in data analyses. Furthermore, the results of this study might be affected by the age of the participants. As they are very young, some factors might not be as important to them as they are for older participants. For example, high working time variability might be more problematic if workers have children to care for. Replicating the results with participants of higher ages and of different occupations would provide more insight. Additionally, as our sample is mainly female, there might be gender specific effects regarding our results. Samuelsson, Houkes, Verdonk and Hammarström (2012) reported a moderating effect of gender on the relation between temporary work and self-reported health. Specifically, male temporary workers reported poorer health than female temporary workers. Future studies should focus on gender specific aspects in flexible work arrangements. The importance of employment-related stress nevertheless holds true beyond the data generated from our sample. Lewchuk and colleagues $(2005,2008)$ did provide data from working populations and their results indicate that employment-related stress is an important aspect of health in more representative samples.

Secondly, task-related aspects of stress were limited to time pressure and control. As these are the most prominent aspects in Karasek's JDC model (1979), we believe this restriction to be justified. However, future studies should include more taskrelated demands and resources.

Thirdly, nearly all effects reported are statistically secured $(1-\beta=.77-.99)$. It should be noted, however, that in order to satisfactorily secure the additional effect of characteristics of working time on SWLS, a sample size of 599 is required. The effect of characteristics of working time on burnout would have required a sample size of 675. The effects are assumed to be larger in other samples, however, because employment-related stress may be even more pronounced in other populations of flexible workers.

Fourthly, the cross-sectional nature of our study does not permit the examination of causal relations. Longitudinal studies are needed to examine the temporal relationship between our variables and address possible reverse causations.

\subsection{Conclusion}

Our results show that besides task-related aspects of stress, specific employmentrelated demands and resources are important for health and well-being in flexible employment. Moreover, drawing on JD-R theory, we were able to expand Lewchuck et al.'s (2005) concept of employment strain and introduced employment-related demands and resources not discussed elsewhere. We demonstrated that employmentrelated demands and resources show incremental validity, as they explain additional variance in levels of health and well-being beyond task-related aspects of stress. These traditional aspects of job design nevertheless remain important. It might be that employees in flexible work arrangements face a twofold risk: 1 . They face poorly designed jobs and 2. they are confronted with new sources of stress stemming from the employment itself. Future studies should focus on different forms of flexible employment and especially on temporary work, as this kind of work is rapidly increasing (OECD, 2010). 


\section{References}

Bakker, A. B., \& Demerouti, E. (2007). The job demands-resources model: State of the art. Journal of Managerial Psychology, 22(3), 309-328.

Bakker, A. B., van Veldhoven, M., \& Xanthopoulou, D. (2010). Beyond the demand-control model. Journal of Personnel Psychology, 9(1), 3-16. doi:10.1027/1866-5888/a000006

Benach, J., Amable, M., Muntaner, C., \& Benavides, F. G. (2002). The consequences of flexible work for health: Are we looking at the right place? Journal of epidemiology and community health, 56(6), 405-6.

Benach, J., Benavides, F. G., Platt, S., Diez-Roux, A., \& Muntaner, C. (2000). The health-damaging potential of new types of flexible employment: A challenge for public health researchers. American Journal of Public Health, 90, 1316-1317.

Benavides, F. G., Benach, J., Diez-Roux, A. V., \& Roman, C. (2000). How do types of employment relate to health indicators? Findings from the Second European Survey on Working Conditions. Journal Epidemiol Community Health, 54, 494-501.

Bentler, P. M., \& Bonett, D. G. (1980). Significance tests and goodness of fit in the analysis of covariance structures. Psychological Bulletin, 88(3), 588-606.

Bernhard-Oettel, C., de Cuyper, N., Berntson, E., \& Isaksson, K. (2008). Well-being and organizational attitudes in alternative employment: The role of contract and job preferences. International Journal of Stress Management, 15(4), 345-363.

Bernhard-Oettel, C., Sverke, M., \& de Witte, H. (2005). Comparing three alternative types of employment with permanent full-time work: How do employment contract and perceived job conditions relate to health complaints? Work \& Stress, 19(4), 301-318.

Berntson, E., \& Marklund, S. (2007). The relationship between employability and subsequent health. Work \& Stress, 21, 279-292.

Berntson, E., Sverke, M., \& Marklund, S. (2006). Predicting perceived employability: Human capital or labour market opportunities? Economic and Industrial Democracy, 27, 223-244.

Berntson, E., Näswall, K., \& Sverke, M. (2010). The moderating role of employability in the association between job insecurity and exit, voice, loyalty and neglect. Economic and Industrial Democracy, 31(2), 215-230.

Browne, M. W., \& Cudeck, R. (1993). Alternative ways of assessing model fit. In K. A. Bollen \& J. S. Long (Eds.), Testing structural equation models (pp. 445-455). Newbury Park, CA: Sage.

Burisch, M. (2007). The Hamburg Burnout Inventory (HBI) in two large international online samples. Hamburg: University of Hamburg.

Butler, A. B., Grzywacz, J. G., Ettner, S. L., \& Liu, B. (2009). Workplace flexibility, self-reported health, and health care utilization. Work \& Stress, 23(1), 45-59.

Bühner, M. (2011). Einfübrung in die Test-und Fragebogenkonstruktion. München: Pearson Studium.

Clarke, M., Lewchuk, W., de Wolff, A., \& King, A. (2007). “This just isn't sustainable': Precarious employment, stress and workers' health. International Journal of Law and Psychiatry, 30(4-5), 311-26.

Costa, G., Akerstedt, T., Nachreiner, F., Baltieri, F., Carvalhais, J., Folkard, S., Dresen, M. F., Gadbois, C., Gartner, J., Grzech Sukalo, H., Härmä, M., Kandolin, I., Sartori, S., \& Silvério, J. (2004). Flexible working hours, health, and well-being in Europe: Some considerations from a SALTSA project. Chronobiology International, 21(6), 831-844.

Costa, G., Sartori, S., \& Akerstedt, T. (2006). Influence of flexibility and variability of working hours on health and well-being. Chronobiology International, 23(6), 1125-37.

Curran, P. J., West, S. G., \& Finch, J. F. (1996). The robustness of test statistics to nonnormality and specification error in confirmatory factor analysis. Psychological Methods, 1(1), 16-29.

De Cuyper, N., Bernhard-Oettel, C., Berntson, E., de Witte, H., \& Alarco, B. (2008). Employability and employees' well-being: Mediation by job insecurity. Applied Psychology, 57(3), 488-509.

De Cuyper, N., van der Heijden, B. I. J. M., \& de Witte, H. (2011). Associations between perceived employability, employee well-being, and its contribution to organizational success: A matter of psychological contracts? International Journal of Human Resource Management, 22(7), 1486-1503.

De Cuyper, N., de Jong, J., de Witte, H., Isaksson, K., Rigotti, T., \& Schalk, R. (2008). Literature review of theory and research on the psychological impact of temporary employment: Towards a conceptual model. International Journal of Management Reviews, 10(1), 25-51. 
De Lange, A. H., Taris, T. W., Kompier, M. A. J., Houtman, I. L. D., \& Bongers, P. M. (2003). "The very best of Millenium": Longitudinal research and the demand-control-(support)-model. Journal of Occupational Health Psychology, 8(4), 282-305.

De Witte, H. (1999). Job insecurity and psychological well-being: Review of the literature and exploration of some unresolved issues. European Journal of Work and Organizational Psychology, 8(2), 155-177.

Demerouti, E., Bakker, A. B., Nachreiner, F., \& Schaufeli, W. B. (2001). The job demands-resources model of burnout. Journal of Applied Psychology, 86, 499-512.

Diener, E., Emmons, R. A., Larsen, R. J., \& Griffin, S. (1985). The satisfaction with life scale. Journal of Personality Assessment, 49, 71-75.

Ducki, A. (2000). Diagnose gesundheitsförderlicher Arbeit. Eine Gesamtstrategie zur betrieblichen Gesundheitsanalyse. Zürich: vdf Hochschulverlag.

D'Souza, R. M., Strazdins, L., Broom, D. H., Rodgers, B., \& Berry, H. L. (2006). Work demands, job insecurity and sickness absence from work. How productive is the new, flexible labour force? Australian and New Zealand Journal of Public Health, 30(3), 205-12.

Ellingson, J. E., Gruys, M. L., \& Sackett, P. R. (1998). Factors related to the satisfaction and performance of temporary employees. Journal of Applied Psychology, 83(6), 913-921.

Everitt, B. S., \& Skrondal, A. (2010). The Cambridge dictionary of statistics (4th Edition). Cambridge: Cambridge University Press.

Guest, D. (2004). Flexible employment contracts, the psychological contract and employee outcomes: An analysis and review of the evidence. International Journal of Management Reviews, 5-6(1), 1-19.

Guest, D. E., Isaksson, K., \& de Witte, H. (2010). Employment contracts, psychological contracts, and employee well-being. An international study. Oxford: Oxford University Press.

Hacker, W. (2002). Action theory, psychological. In N. J. Smelser \& P. B. Baltes (Eds.), International encyclopedia of the social and behavioral sciences (pp. 58-62). London: Elsevier.

Hacker, W. (2003). Action regulation theory: A practical tool for the design of modern work processes. European Journal of Work and Organizational Psychology, 12, 105-130.

Hackman, J. R., \& Oldham, G. R. (1980). Work redesign. Reading, MA: Addison-Wesley.

Hillage, J., \& Pollard, E. (1998). Employability: Developing a framework for policy analysis. Research Report No 85. Department for Education and Employment.

Hu, L.-T., \& Bentler, P. M. (1999). Cutoff criteria for fit indexes in covariance structure analysis: Conventional criteria versus new alternatives. Structural Equation Modeling, 6(1), 1-55.

Häusser, J. A., Mojzisch, A., Niesel, M., \& Schulz-Hardt, S. (2010). Ten years on: A review of recent research on the job demand-control (-support)-model and psychological well-being. Work \& Stress, 24(1), 1-35.

Isaksson, K., \& Bellagh, K. (2002). Health problems and quitting among female "temps." European Journal of Work and Organizational Psychology, 11(1), 27-45.

Jahoda, M. (1982). Employment and unemployment: A social-psychological analysis. Cambridge: Cambridge University Press.

Janssen, D., \& Nachreiner, F. (2005). Reliability and predictability of flexible working hours - Effects on health and well-being. Shiftwork International Newsletter, 22(2), 79.

Janssen, D., \& Nachreiner, F. (2004a). Health and psychosocial effects of flexible working hours. Revista de saúde pública, 38 Suppl, 11-8.

Janssen, D., \& Nachreiner, F. (2004b). Flexible Arbeitszeiten. Bremerhaven: Wirtschaftsverlag NW.

Johnson, J. V., \& Hall, E. M. (1988). Job strain, work place social support and cardiovascular disease: A cross-sectional study of a random sample of the Swedish working population. American Journal of Public Health, 78, 1336-1342.

Karasek, R. A. (1979). Job demands, job decision latitude, and mental strain: Implications for job design. Administrative Science Quarterly, 24, 285-308.

Kattenbach, R., Demerouti, E., \& Nachreiner, F. (2010). Flexible working times: Effects on employees' exhaustion, work-nonwork conflict and job performance. Career Development International, 15(3), 279295. 
Kivikäki, M., Vahtera, J., Virtanen, M., Elovainio, M., Pentti, J., \& Ferrie, J. E. (2003). Temporary employment and risk of overall and cause-specific mortality. American Journal of Epidemiology, 158(7), 663-668.

Kline, R. B. (2005). Principles and practice of structural equation modeling. New York: The Guilford Press.

Krausz, M. (2000). Effects of short-and long-term preference for temporary work upon psychological outcomes. International Journal of Manpower, 21(8), 635-647.

Lewchuk, W., Clarke, M., \& de Wolff, A. (2008). Working without commitments: Precarious employment and health. Work, Employment \& Society, 22(3), 387-406.

Lewchuk, W., de Wolff, A. D., King, A., \& Polanyi, M. (2003). From job strain to employment strain: Health effects of precarious employment. Just Labour, 3, 23-35.

Lewchuck, W., de Wolff, A. D., King, A., \& Polanyi, M. (2005). Beyond job strain: Employment strain and the health effects of precarious employment. Working in a Global Society Working Papers, 1.

Lundberg, U., \& Lindfors, P. (2002). Psychophysiological reactions to telework in female and male whitecollar workers. Journal of Occupational Health Psychology, 7(4), 354-364.

Marler, J. H., Woodard Barringer, M., \& Milkovich, G. T. (2002). Boundaryless and traditional contingent employees: Worlds apart. Journal of Organizational Behavior, 23(4), 425-453.

McGrath, J. E., \& Beehr, T. A. (1990). Time and the stress process: Some temporal issues in the conceptualization and measurement of stress. Stress Medicine, 6(2), 93-104.

Mohr, G., \& Müller, A. (2005). Psychosomatische Beschwerden im nichtklinischen Kontext. In A. Glöckner-Rist (Ed.), ZUMA-Informationssystem. Elektronisches Handbuch sozialwissenschaftlicher Erbebungsinstrumente. Version 8.00. Mannheim: Zentrum für Umfragen, Methoden und Analysen.

Mohr, G., Rigotti, T., \& Müller, A. (2005). Irritation - Ein Instrument zur Erfassung psychischer Beanspruchung im Arbeitskontext. Skalen- und Itemparameter aus 15 Studien. Zeitschrift für Arbeits- und Organisationspsychologie, 49, 44-48.

Moosbrugger, H., \& Schermelleh-Engel, K. (2007). Exploratorische (EFA) und Konfirmatorische Faktorenanalyse (CFA). In H. Moosbrugger \& A. Kelava (Eds.), Testtheorie und Fragebogenkonstruktion (pp. 307-324). Berlin: Springer.

Organisation for Economic Co-operation and Development (OECD) (2002). Taking the measure of temporary employment. OECD Employment Outlook 2002. Paris: OECD Publishing.

Organisation for Economic Co-operation and Development (OECD) (2010). OECD Employment Outlook 2010: Moving beyond the jobs crisis. Paris: OECD Publishing.

Polivka, A. E. (1996). Into contingent and alternative employment: By choice? Monthly Labor Review, (October), 55-74.

Rau, R. (2006). Learning opportunities at work as predictor for recovery and health. European Journal of Work and Organizational Psychology, 15(2), 158-180.

Reisel, W. D., Probst, T. M., Chia, S.-L., Maloles, C. M., \& König, C. J. (2010). The effects of job insecurity on job satisfaction, Organizational citizenship behavior, deviant behavior, and negative emotions of employees. International Studies of Management and Organization, 40(1), 74-91.

Samuelsson, A., Houkes, I., Verdonk, P., \& Hammarström, A. (2012). Types of employment and their associations with work characteristics and health in Swedish women and men. Scandinavian journal of public health, 40(2), 183-90.

Semmer, N. K. (1984). Streßbezogene Tätigkeitsanalyse: Psychologische Untersuchungen zur Analyse von Streß am Arbeitsplat: Weinheim: Beltz.

Semmer, N., Zapf, D., \& Dunckel, H. (1998). ISTA - Instrument zur Stressbezogenen Arbeitsanalyse. Version 6.0. Bern, Frankfurt, Flensburg.

Stevens, J. P. (2009). Applied multivariate statistics for the social sciences (5th ed.). New York: Routledge.

Sverke, M., Hellgren, J., \& Näswall, K. (2002). No security: A meta-analysis and review of job insecurity and its consequences. Journal of Occupational Health Psychology, 7(3), 242-264.

Zimet, G. D., Dahlem, N. W., Zimet, S. G., \& Farley, G. K. (1988). The multidimensional scale of perceived social support. Journal of Personality Assessment, 52, 30-41. 